\title{
IDENTIFIKASI FORMALIN PADA CINCAU YANG DIPERJUALBELIKAN DI BEBERAPA PASAR AREA KOTA MAKASSAR
}

\author{
Waode Rustiah $^{1)}$, Tuty Widyanti ${ }^{1)}$, Andi Fatmawati ${ }^{1)}$, Yuwalida ${ }^{1)}$ \\ ${ }^{1)}$ Prodi DIII Teknologi Laboratorium Medis Politeknik Kesehatan Muhammadiyah Makassar \\ Alamat Korespondensi:waoderustiah79@gmail.com
}

\begin{abstract}
Abstrak
Cincau merupakan salah satu jenis makanan yang digemari oleh masyarakat, cincau merupakan produk yang memiliki karakteristik mudah rusak sehingga perlu dilakukan pengawetan. Bahan pengawet yang umumnya digunakan untuk mengawetkan pangan yang mempuanyai sifat mudah rusak, hal ini menyebabkan beberapa pedangang menggunakan bahan tambahan yang berbahaya dan dilarang penggunaannya pada makanan oleh pemerintah seperti Formalin. Tujuan penelitian ini adalah untuk mengidentifikasi formalin pada cincau yang diperjualbelikan di beberapa pasar di Kota Makassar. Jenis penelitian ini bersifat eksperimen laboratorik dengan teknik analisa kualitatif. Sampel yang digunakan dalam penelitian ini adalah sampel cincau, sebanyak 10 sampel yang diambil dari beberapa pedangang di 5 Pasar tradisional dan 1 sampel di Supermarket. Teknik pengambilan sampel adalah Sampling Accidental. Hasil penelitian menunjukkan bahwa 10 sampel yang diambil di beberapa pasar dengan inisial $S G$ 1, $S G$ 2, $P B$ 1, $P B$ 2, $A B$ 1, AB 2, TL 1, $T L$ 2, MC 1, SP 1 dinyatakan tidak mengandung formalin atau hasil Negatif(-).
\end{abstract}

Kata Kunci: Formalin, Cincau

\section{PENDAHULUAN}

Makanan merupakan sumber energi dan gizi, tanpa makanan manusia tidak memiliki tenaga untuk menjalankan kegiatan sehari-hari. Makanan yang sehat dengan kandungan gizi yang lengkap serta aman merupakan syarat mutlak yang harus dipenuhi pada bahan pangan (Riandini, 2008).

Cincau adalah salah jenis makanan yang digemari oleh masyarakat. Cincau merupakan tumbuhan yang dapat menjadi bahan utama pembuatan jeli atau sirup, cincau dapat dikonsumsi oleh semua kalangan. Bahan ini sangat kaya dengan mineral terutama kalsium dan fosfor. Di lingkungan masyarakat cincau yang lebih banyak dikenal yaitu cincau hitam. Cincau hitam atau lebih dikenal dengan nama janggelan merupakan salah satu jenis tanaman cincau yang banyak dibudidayakan dan dimanfaatkan oleh masyarakat di Indonesia. Cincau merupakan produk yang memiliki karakteristik mudah rusak sehingga perlu dilakukan pengawetan (Bobby dan Tri, 2014).
Bahan pengawet yang umumnya digunakan untuk mengawetkan pangan yang mempunyai sifat mudah rusak. Bahan ini dapat menghambat atau memperlambat proses fermentasi, pengasaman, atau penguraian yang disebabkan oleh mikroba. Akan tetapi, tidak jarang produsen menggunakannya pada pangan yang relatif tidak awet dengan tujuan untuk memperpanjang masa simpan atau memperbaiki tekstur (Cahyadi, 2009).

Adapun bahan kimia berbahaya yang bukan ditujukan untuk makanan justru ditambahkan kedalam makanan seperti formalin, boraks, rhodamin B, methanil yellow. Diantara beberapa jenis bahan kimia berbahaya tersebut yang paling sering digunakan secara bebas di masyarakat adalah boraks dan fomalin (Purwiyatno dan Ratih, 2009).

Pada tahun 2009 di Tangerang Selatan, Badan Pengawasan Obat-obatan dan Makanan (BPOM) menemukan peredaran makanan cincau hitam mengandung bahan pengawet yaitu formalin. Dari sejumlah sampel yang di 
pemeriksa salah satunya adalah cincau. Cincau hitam sebagai bahan makanan pencampur es yang biasa kita minum terbukti menggunakan bahan pangawet mayat atau biasa dikatakan formalin (Anonim, 2009). Formalin pada umumnya digunakan untuk bahan pengawet mayat dan berbagai jenis industri non makanan. Penggunaan formalin sebagai bahan pangawet makanan sangat membahayakan konsumen. Dampak yang terjadi jika kadar formalin terakumulasi dalam tubuh melebihi batas adalah mulai dari terganggunya fungsi sel hingga kamatian sel yang selanjutnya menyebabkan kerusakan pada jaringan dan organ tubuh. Pada tahap selanjutnya dapat pula terjadi penyimpangan dari pertumbuhan sel. Sel-sel tersebut akhirnya berkembang menjadi sel kanker (Ratnasari, 2015).

Formalin merupakan bahan tambahan kimia yang efesien, tetapi dilarang ditambahkan pada bahan pangan (makanan). Di pasaran formalin bisa ditemukan dalam bentuk yang sudah diencerkan, dengan kandungan formaldehide $10-40 \%$. Besarnya manfaat formalin dibidang industri tersebut ternyata disalahgunakan untuk pengawetan industri makanan. Biasanya hal ini sering di temukan dalam industri rumahan karena mereka tidak terdaftar dan tidak terpantau oleh Depkes dan Balai POM setempat Berdasarkan Peraturan Menteri Kesehatan No. 1168/MenKes/Per/IX/1999 formalin dinyatakan sebagai bahan berbahaya dan dilarang untuk digunakan dalam pembuatan makanan.

Seperti yang telah diuraikan di atas bahwa begitu mudahnya masyarakat untuk menambahkan bahan pengawet pada makanan yang dijual di pasaran dengan harga yang sedemikian murah membuat pedagang seringkali menggunakan bahan kimia non pangan sebagai pengawet dalam berbagai jenis makanan seperti tahu, ikan asin, mie basah dan daging ayam.
Beberapa data penelitian tentang
Cincau yang mengandung bahan berbahaya. Menurut Athaya dkk pada Tahun 2017 tentang Identifikasi Boraks pada Cincau Hitam yang Diproduksi Beberapa Produsen Cincau Hitam di Kota 3 Padang. Berdasarkan penelitian yang telah dilakukan terhadap 18 sampel cincau hitam yang dijual pada beberapa pasar di Kota Padang dan diproduksi oleh 18 produsen yang berbeda didapatkan 16 sampel cincau hitam dinyatakan positif mengandung boraks. Menurut Balai Besar Pengawas Obat dan Makanan (BBPOM) dimuat dalam berita Tribun News Medan (Kurniawan, 2018). Waspada Cincau Berformalin Beredar Di Pasaran, menemukan peredaran cincau hitam berformalin di pasaran pada Mei Tahun 2018 terhadap sampel yang diambil dari pasar tradisional Langkat di Kota Medan menemukan 3 drum formalin ukuran 25 $\mathrm{Kg}$. Selain menyita formalin, petugas juga menemukan 5 ton cincau yang sudah dicampur dengan zatberbahaya tersebut.

Dari uraian di atas, maka pada penelitian ini dilakukan identifikasi formalin pada cincau yang diperjualbelikan di beberapa pasar area kota Makassar.

\section{METODOLOGI PENELITIAN}

Alat dan Bahan

Alat yang digunakan pada penelitian ini adalah: alat destilasi, neraca analitik, lemari asam, hot plate, gelas kimia, sendok tanduk, Erlenmeyer, batu didih. Sedangkan bahan yang digunakan dalam penelitian ini adalah: Cincau, Aquadest, $\mathrm{H}_{3} \mathrm{PO}_{4}$ pekat, formaldehide, $\mathrm{CH}_{2} \mathrm{O}-1$ (asam sulfat), $\mathrm{CH}_{2} \mathrm{O}-2$ (asam kromatofat).

\section{Prosedur Penelitian \\ Preparasi sampel}

Sampel terlebih dahulu digerus hingga halus, kemudian dihomogenkan. Kemudian sampel ditimbang sebanyak 10 gram lalu dimasukkan ke dalam gelas kimia, kemudian ditambahkan dengan aquadets sebanyak $100 \mathrm{ml}$, kemudian ditambahkan $20 \mathrm{ml}$ larutan $\mathrm{H}_{3} \mathrm{PO}_{4}$ p.a, lalu dimasukkan ke dalam labu destilasi, 
segera dilanjutkan dengan destilasi hingga diperoleh total volume destilasi 30-50 $\mathrm{mL}$.

Pemeriksaan secara kualitatif dengan uji Asam Kromatofat (Pereaksi Spektro Quantmerck). Sampel dari hasil destilasi ditampung sebanyak 30-50 ml ke dalam tabung nessler, Kemudian larutan $\mathrm{CH}_{2} \mathrm{O}-1$ dipipet sebanyak 4,5 ml, Lalu ditambahkan 1 mikroskun $\mathrm{CH}_{2} \mathrm{O}-2$ kedalam tabung, Kemudian tambahkan 3 $\mathrm{mL}$ hasil dari destilasi, dan homogenkan, lalu didiamkan selama 10 menit, dan diamati perubahan warna yang terjadi, selanjutnya dibandingkan perubahan warna sampel dengan kontrol.

Untuk kontrol positif dipipet larutan $\mathrm{CH}_{2} \mathrm{O}-1$ sebanyak $4,5 \mathrm{ml}$, lalu di tambahkan 1 mikroskun $\mathrm{CH}_{2} \mathrm{O}-2$ ke dalam tabung, kemudian ditambahkan lagi sebanyak $3 \mathrm{ml}$ kontrol positif (formalin), lalu dihomogenkan, setelah itu didiamkan selama 10 menit dan diamati perubahan warna yang terjadi.

Untuk kontrol negarif dipipet larutan $\mathrm{CH}_{2} \mathrm{O}-1$ sebanyak $4,5 \mathrm{ml}$, lalu ditambahkan 1 mikroskun $\mathrm{CH}_{2} \mathrm{O}-2$ ke dalam tabung, kemudian ditambahkan 3 $\mathrm{ml}$ kontrol negatif (aquadest) lalu dihomogenkan, setelah itu didiamkan selama 10 menit dan diamati perubahan warna yang terjadi.

\section{HASIL PENELITIAN}

Pangan adalah segala sesuatu yang berasal dari sumber hayati produk pertanian, perkebunan, kehutanan, perikanan, peternakan, perairan dan air, baik yang diolah maupun tidak diolah, yang diperuntukkan sebagai makanan atau minuman bagi konsumsi manusia termasuk Bahan Tambahan Pangan (BTP), bahan baku pangan dan bahan lain yang digunakan dalam proses penyiapan, pengolahan dan atau pembuatan makanan atau minumanMenurut (BPOM, 2016). Penggunaan bahan tambahan pangan pada makanan perlu mendapatkan perhatian khusus, baik oleh produsen dan konsumen. Dampak penggunaannya dapat berakibat positif maupun negatif untuk masyarakat (Cahyadi, 2009).

Isu keamanan pangan menjadi penting mengingat banyak masyarakat yang kurang peduli dan adanya masyarakat lain yang memanfaatkan ketidakpedulian ini dengan menggunakan bahan pengawet beracun ke dalam makanan dan minuman yang kita konsumsi. Sebut saja penggunaan formali, boraks dan rhodamin dalam makanan dan minuman.

Metode Analisa PPOMN No 033//MM/00 Tahun 2012 adalah reaksi spesifik untuk mengidentifikasi larutan formaldehid dalam pembentukan warna dengan asam kromatropat. Reaksi ini terjadi berdasarkan kondensasi formaldehid dengan sistem aromatik dari asam kromatropat. Senyawa yang mengandung formaldehid mudah dibebaskan dengan adanya Asam Kromatropat dipanaskan dengan Asam Sulfat, maka dalam beberapa menit akan terjadi perubahan warna ungu (+) formalin.

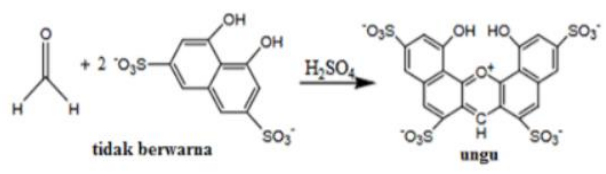

Berdasarkan

pemeriksaan laboratorium secara kualitatif pada 10 jenis sampel cincau yang diambil di beberapa pasar tradisional dan 1 sampel diambil dari supermarket sebagai pembanding di kota Makassar, menggunkan 10 sampel (SP, MC 1, SG 1, SG 2, PB 1, PB 2, AB 1, AB 2, TL 1, TL 2) dinyatakan Negatif tidak mengandung formalin.

Hasil dari pemeriksaan ini membuktikan bahwa cincau yang diperjualbelikan di beberapa pasar di area kota Makassar tidak mengandung formalin karena pada saat sampel ditambahkan dengan $\mathrm{CH}_{2} \mathrm{O}-1$ (asam sulfat), dan $\mathrm{CH}_{2} \mathrm{O}-2$ (asam kromatofat) tidak terbentuk adanya reaksi, hal ini ditandai dengan tidak terjadinya perubahan warna menjadi ungu di dalam 
sampel yang diteliti. Apabila sampel mengandung formalin, maka hasil yang diunjukkan akan terjadi perubahan warna ungu pada sampel yang diteliti. Walaupun sampel diambil di beberapa pasar tradisional yang keadaan pasar tersebut berada di pinggir jalan dimana pasar tersebut banyak debu dan asap-asap kendaraan dan lingkungan disekitarnya kurang bersih. Oleh karena hasil pemeriksaan yang didapat negatif tidak berarti bahan makanan (cincau) yang dijual diberi tambahan pengawet seperti formalin. Maka hal ini tidak akan berdampak buruk bagi masyarakat apabila ingin mengkonsumsi cincau yang diperjualbelikan di pasaran. Sesuai dengan Peraturan Menteri Kesehatan Nomor 1168/Menkes/Per/X/1999 dimana formalin tidak diizinkan ditambahkan ke dalam bahan makanan atau digunakan sebagai pengawet makanan karena sangat berbahaya bagi kehidupan manusia. Tidak ditemukannya formalin pada cincau yang dijual di Pasar tradisional juga kemungkinan karena pemilik dan pekerja pabrik tempat pengolah atau pembuat cincau masih memiliki kesadaran dan kepedulian akan kesehatan dan keselamatan konsumennya.

\section{KESIMPULAN}

Berdasarkan penelitian yang dilakukan bahwa semua sampel cincau yang dikumpulkan dari beberapa pasar di kota Makassar tidak mengandung formalin.

\section{DAFTAR PUSTAKA}

Abdul R, 2007. Kimia Farmasi Analisis. Pustaka Pelajar : Yogyakarta

Anonim. 2009. http://m.republika.co.id/berita/sho rtlink. (Diunduh 13 April 2016).

Athaya, RZ, et.al., 2017. Identifikasi Boraks Pada Cincau yang Diperoduksi Beberapa Produsen Cincau Hitam di Kota Padang. Jurnal FK Unand. Vol. 6. No. 1. http://jurnal.fk.unand.ac.id

BPOM., 2016 Peraturang Kepala Badan Pengawas Obat Dan Makanan
Republik Indonesia,No 18,Tentang Pangan. Cahyadi, W., 2009.Analisa \&Aspek Kesehatan Bahan Tambahan Pangan Jakarta. Bumi Aksara

Bobby, A dan Tri, D. 2014 . Peranan Minuman Cincau Hitam Terhadap Penurunan Tekanan darah. (Online). Vol 2, No 3 (http://jpa.ub.ac.id.)

Cahyadi, W. 2006. Kajian dan Analisis Bahan Tambahan Pangan, Edisi Pertama. Bumi Aksara : Jakarta

Cahyadi, W. 2009. Kajian dan Analisis Bahan Tambahan Pangan, Edisi kedua. Bumi Aksara : Jakarta

Frank Lu. 2006. Toksikologi Dasar Asas, Organ Sasaran, dan Penilaian Risiko, Edisi Kedua. Universitas Indonesia (UI press) : Jakarta.

Hidayanti D, Saparinto C, 2006. Bahan tambahan pangan. Kanisius : Yogyakarta.

Kurniawan, D., 2018. Waspada Cincau Berformalin Beredar di Pasaran. Available at [Accessed 28 May 2018].

Kementrian Kesehatan Republik Indonesia,Balai Besar Laboratorium Kesehatan Makassar (BBLK). 2014

Peraturan Menteri Kesehatan Republik Indonesia Nomor 1168/Menkes/Per/Ix/1999

Pratiwi, T. S. Mikrobiologi Farmasi. Erlangga: Yogyakarta.

Purwiyatno, H. Dan Ratih, D. H.2009. Petunjuk Sederhana Memproduksi Pangan Yang Aman. Dian Rakyat: Jakarta

Ratnasri S. 2015. Identifikasi Formalin pada Bakso Dari Pedangan Bakso Di Kecamatan Panakukang Kota Makassar. http://repository. unhas.ac.id.

Riandini, N. 2008. Seri Kimia Dalam kehidupan Sehari-hari : Bahan Kimia dalam Makanan dan Minuman. Shakti Adiluhung: Bandung 
Riana. 2015. Kandungan Formalin Dan Kadar Garam Pada Ikan Sunu Asin Dari Pasar Tradisional Makassar.

http://repository.unhas.ac.id.

Sartono. 2002. Racun dan Keracunan. Widya Medika. Jakarta

Sanny.S. 2010. Penetapan Kadar Formalin pada Tahu yang Dijual Pasar dengan Metode spektrofotometry. (http://repository.uinjkt.ac.id).

Yuliarti. N. 2007. Awas Bahaya Dibalik Lezatnya Makanan. CV Andi Offset. Yogyakarta 